\title{
Remembering Dr. Henry W. Gray (1827-1861) and His Timeless Contribution to Modern Medical Education.
}

\author{
Niti Shahi \\ Thomas Jefferson University \\ Abigail L. Brooks \\ Thomas Jefferson University \\ Charles J. Yeo \\ Thomas Jefferson University \\ Scott W. Cowan \\ Thomas Jefferson University
}

Gerald A. Isenberg

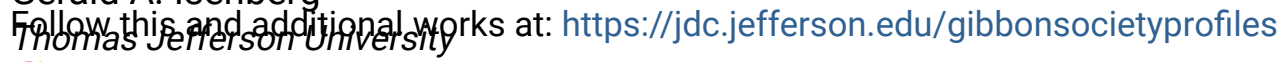

Part of the History of Science, Technology, and Medicine Commons, and the Surgery Commons Let us know how access to this document benefits you

\section{Recommended Citation}

Shahi, Niti; Brooks, Abigail L.; Yeo, Charles J.; Cowan, Scott W.; and Isenberg, Gerald A., "Remembering Dr. Henry W. Gray (1827-1861) and His Timeless Contribution to Modern Medical Education." (2016). Department of Surgery Gibbon Society Historical Profiles. Paper 46.

https://jdc.jefferson.edu/gibbonsocietyprofiles/46

This Article is brought to you for free and open access by the Jefferson Digital Commons. The Jefferson Digital Commons is a service of Thomas Jefferson University's Center for Teaching and Learning (CTL). The Commons is a showcase for Jefferson books and journals, peer-reviewed scholarly publications, unique historical collections from the University archives, and teaching tools. The Jefferson Digital Commons allows researchers and interested readers anywhere in the world to learn about and keep up to date with Jefferson scholarship. This article has been accepted for inclusion in Department of Surgery Gibbon Society Historical Profiles by an authorized administrator of the Jefferson Digital Commons. For more information, please contact: JeffersonDigitalCommons@jefferson.edu. 


\title{
Remembering Dr. Henry W. Gray (1827-1861) and His Timeless Contribution to Modern Medical Education
}

\author{
NITI SHAHI, M.D., ABIGAIL L. BROOKS, B.A., CHARLES J. YEO, M.D., SCOTT W. COWAN, M.D., \\ GERALD A. ISENBERG, M.D. \\ From Department of Surgery, Sidney Kimmel Medical College, Thomas Jefferson University, \\ Philadelphia, Pennsylvania
}

1 N 1858 SIR HENRY WILLIAMSON GRAY (1827-1861) revolutionized the study of anatomy and the practice of surgery by publishing Anatomy: Descriptive and Surgical; the widely used anatomical textbook composed of a vast number of precise anatomical illustrations. Dr. Gray, the Father of Modern Anatomy, in addition to being a surgeon, lecturer, and curator at St. George's Hospital in London, recognized the need for an affordable and accurate textbook for medical students. Dr. Gray is credited with the authorship of this anatomical masterpiece. It is only with the illustrations of Dr. Henry Vandyke Carter (1831-1897), an English surgeon, professor, and artist that Gray's Anatomy is distinct from previous anatomical textbooks. Dr. Gray and Dr. Carter's intention was to produce a textbook beyond the traditional study of anatomy and create an "application of this science to practical surgery."1

Sir Henry Williamson Gray was born in Belgravia, London, United Kingdom, without a trace of medical heritage (Fig. 1). Thomas Gray, his father, was a private messenger to King George IV and his successor, William IV. Dr. Gray learned from his father how to be observant and inconspicuous, two vital traits that would later shape the making of Gray's Anatomy. ${ }^{2} \mathrm{He}$ was one of four children, with two brothers and a sister. His sister and one of his brothers passed away at a young age. Dr. Gray was a language aficionado, speaking French, German, and Italian. ${ }^{1}$ In May 1845 , he enrolled at St. George's Medical School in London.

All Dr. Gray was certain about was his desire to attend medical school, "it is almost as if Henry Gray did not fully exist as a flesh and blood being until the sixth of May 1845 the day he stepped inside London's St. George's Hospital and signed his name to register as a medical student." ${ }^{2} \mathrm{He}$ had a passion for anatomy

Address correspondence and reprints requests to Scott W. Cowan, M.D., Department of Surgery, Thomas Jefferson University, 1100 Walnut Street, 5th Floor, Philadelphia, PA 19107. E-mail: scott.cowan@jefferson.edu. and was said to be the "most painstaking and methodical worker."' Throughout medical school, he explored his propensity toward anatomy by preparing his own elaborate dissections to supplement his learning. In fact, he invested in writing an award-winning essay comprised with illustrations of dissections entitled "Anatomy and Physiology of Nerves of the Human Eye." ${ }^{1}$ During his final year of medical school, Dr. Gray even became a postmortem examiner.

In 1850, Dr. Gray became the House Surgeon to St. George's Hospital. Beyond anatomy, he had an interest in embryology, leading to his work titled "The Glands of Chicks." "At the age of 25, he was elected as a Fellow of the Royal Society, a distinctive honor for a young surgeon. As a Fellow of the Royal Society, Dr. Gray joined the ranks of the famed physicist Isaac Newton and microbiologist pioneer Antonie van Leeuwenhoek. ${ }^{2}$ Dr. Gray further embraced his passion for anatomy, when he became a lecturer of anatomy and curator of the museum at St. George's Hospital. Dr. Gray's compendium of anatomical texts extended with the achievement of winning the Astley Cooper Prize for his dissertation "The structure and use of the spleen." ${ }^{1}$ His multifaceted interests in research and education bridged anatomy with other essential disciplines in medicine. In May 1848, the final year of medical school for Dr. Gray, Henry Vandyke Carter registered to be a medical student at St. George's Hospital. At St. George's Hospital, Dr. Gray and Dr. Carter became acquainted with each other when Dr. Gray became Dr. Carter's lecturer of anatomy. The unusual duo shared a passion for anatomy. Their first work together was 380 pages, with 65 wood engravings on the development, anatomy, and physiology of the spleen. ${ }^{1}$ This dissertation involved systematic measuring of the spleen at different ages. It was the earliest description of the lymphatic and nervous system and elaborated on histology and blood supply. It distinguished the spleen from adjacent anatomical structures and detailed the embryology of the spleen. 
In 1856, Drs. Gray and Carter began their collaborative efforts to create the most coveted anatomical textbook in history. Anatomy textbooks had been in circulation for more than 500 years. At the time, Quain's Elements of Anatomy was a commonly used text and was undergoing revisions to its sixth edition. Dr. Gray and Dr. Carter stressed the utilitarian impact of their text, urging it would be useful after entering the professional world. ${ }^{3}$ Since 1847 , the medical world had been in transition because of the compelling discovery of the first anesthesia, chloroform. ${ }^{2}$ Surgeons now had a need for retrieving a larger scope of knowledge because anesthesia enabled surgeons to access deeper and previously unreachable anatomy.

The making of the written masterpiece was a painstaking process. Dr. Gray and Dr. Carter diligently worked for nine hours at a stretch. ${ }^{3}$ The exacting

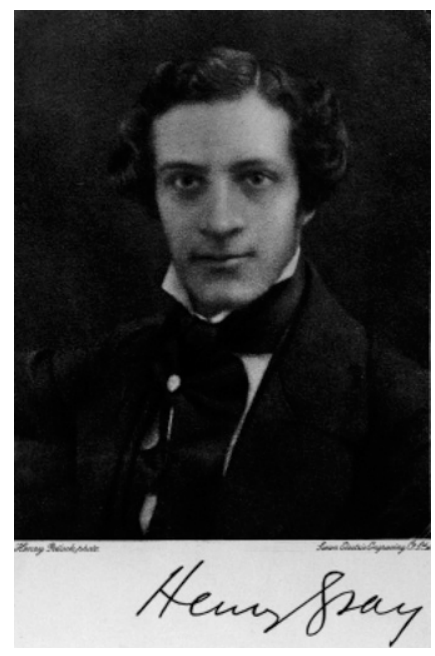

FIG. 1. Portrait of Dr. Henry Gray. Available at: http://www. sciencemuseum.org.uk/broughttolife/people/henrygray.aspx. Accessed July 30, 2015. process involved dissections by Dr. Gray, Dr. Carter's meticulous drawings by paper, transference of the illustrations by draftsmen, and lastly the engraving of the woodblock. ${ }^{4}$ It was only later on that Dr. Carter would hasten the process by drawing the illustrations directly on the woodblock. The primary intention of this textbook was "to supply an affordable, accurate teaching aid for people like their own students." Anatomy: Descriptive and Surgical, later known as Gray's Anatomy, distinguished itself from prior anatomy textbooks in circulation by being "simple, wellillustrated and well-organized." 3 Dr. Carter's drawings were more conducive to learning than prior books due to the direct labeling on anatomical structures. ${ }^{5}$ Figure 2 illustrates Carter's nomenclature system. Previous anatomy books such as famed texts by Quain and Wilson had illustrations too miniaturized to be realistic. ${ }^{3}$ Dr. Carter innovated detailed, magnified illustrations compared with the standard rudimentary and vague drawings in the circulating anatomy books. ${ }^{5}$ Dr. Carter's images were distinct and valued because of his highly skilled shadowing and drawing of subjects as if they were anesthetized. The first edition included over 400 anatomical drawings. The anatomical text was masterfully organized by Dr. Gray and Dr. Carter's subdivision into precise sections: osteology articulations, the muscles and fasciae, the arteries, the veins, the lymphatics, the nervous system and organs of sense, the viscera, regional anatomy, and microscopial anatomy. ${ }^{1}$ Dr. Gray depended on the help of his friend Dr. Timothy Carter to serve as the editor and propel the publication process. Their final product doubly surpassed the scope of knowledge of Quain's Anatomy.

Dr. Gray received full authorship of the textbook despite Dr. Carter's significant contribution. Dr. Gray

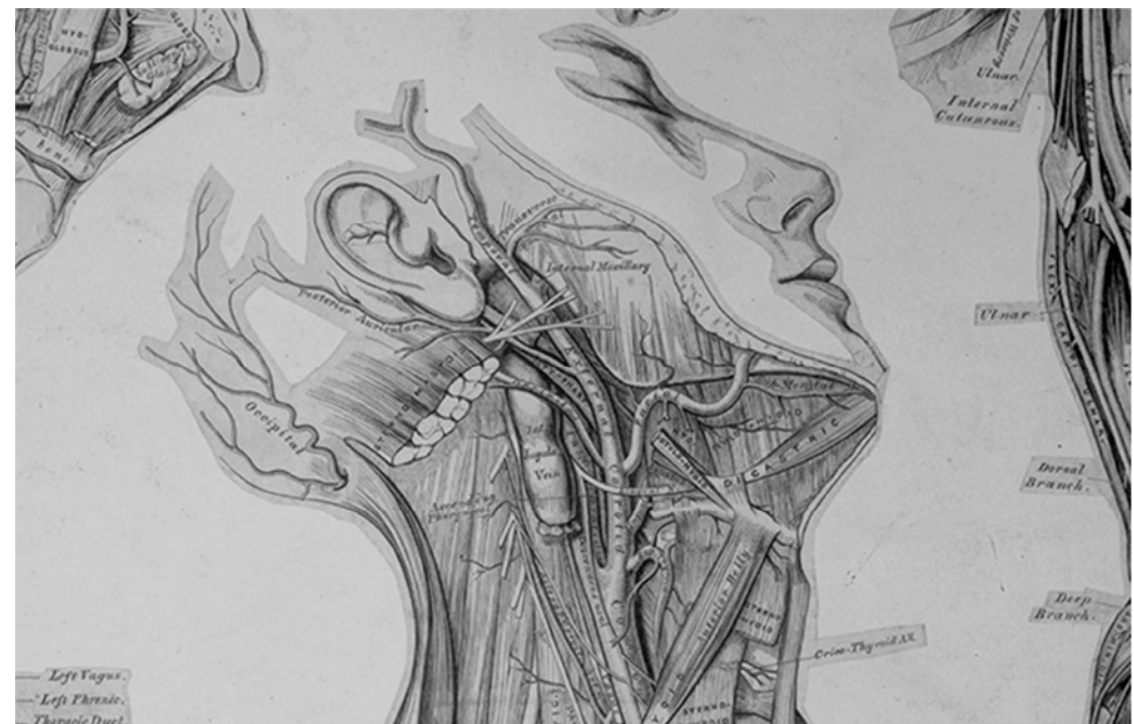

FIG. 2. The upper vascular system engraving from the first edition of Gray's Anatomy. Available at: https:// www.rcseng.ac.uk/museums/hunterian/ images/grays-anatomy/grays_anatomy_ image.jpg. Accessed July 30, 2015. 
was paid 150 pounds per every thousand copies whereas Dr. Carter only received a onetime payment. ${ }^{3}$ Embittered by Dr. Gray's refusal to pay him royalties, Dr. Carter joined the Bombay Medical Service. In 1858, Dr. Carter returned to his passion for medical education when he assumed the position of Professor of Anatomy and Physiology at Grant Medical College in India. ${ }^{3}$ Later in his lifetime, Dr. Carter pioneered the research and study of leprosy and mycetoma, a chronic granulomatous fungal infection below the skin. ${ }^{3}$

Gray's Anatomy received high acclaims with its first publication in Britain. The British medical journal, The Lancet, not one to easily give praise, professed that Gray's Anatomy was "the best anatomy treatise in any language and called Henry Vandyke Carter's illustrations perfect." 2 The reviews stressed "the logical arrangement of the subject matter, the inclusion of practical points directed toward stimulating the student, the effectiveness of the illustrations, their originality and clarity and the close correlation between illustrations and text." ${ }^{\text {"H How- }}$ ever, there were several criticisms from American journals for the oversimplification and lack of color of the illustrations for medical students. Even the journals that had critiques praised Dr. Gray for his efforts.

The textbook was popular and desired beyond Britain. A Philadelphia publisher made arrangements to secure its publishing in America just one year later. By the next year, Dr. Gray began working on a second edition. Gray's Anatomy has been widely considered as one of the most famed books in the English language and as the sole medical text known by its name. ${ }^{2}$ Nearly 160 years later with 40 editions, Gray's Anatomy remains as the forerunner in anatomical texts in medical schools worldwide. With millions of copies sold and its translation into more than a dozen languages, Gray's Anatomy has been educating medical students for generations. Despite being published in Britain by three British doctors, Gray's Anatomy has had a worldwide impact for generations of future physicians. It has never gone out of print. Gray's Anatomy is the cornerstone of anatomy and hence surgery, serving as the rite of passage for all medical students alike as the quintessential "medical bible."

\section{REFERENCES}

1. Goss CM. A Brief Account of Henry Gray, FRS, and His Anatomy, Descriptive and Surgical: During a Century of its Publication in America. Philadelphia: Lea \& Febiger, 1959.

2. Hayes B. The Anatomist: A True Story of Gray's Anatomy. New York: Ballantine Books, 2008.

3. Standring S. Gray's Anatomy, 40th Ed. Edinburg, Scotland: Churchill Livingstone/Elsevier, 2008.

4. Netter F, Friedlaender GE. Frank H. Netter MD and a brief history of medical illustration. Clin Orthop Relat Res 2014;472:812-9.

5. Ghosh SK. Evolution of illustrations in anatomy: a study from the classical period in Europe to modern times. Anat Sci Educ 2015;8:175-88. 